\title{
In the shadows of power: the infrastructural violence of thermal power generation in Ghana's coastal commodity frontier
}

\author{
Callum Nolan ${ }^{1}$ \\ Michael K. Goodman \\ Filippo Menga \\ University of Reading, UK
}

\begin{abstract}
This research adopts Jason Moore's concept of the commodity frontier, which portrays the socio-ecological impacts of capitalist expansion, to analyze the spread of Independent Power Provision in Sub-Saharan Africa. This form of power provision has thus far been under-theorized, especially its impacts on local communities, which must be addressed considering its contemporary popularity in the region. The article uses the concept of 'infrastructural violence' as an analytical lens, drawing upon its language and theories that describe the ways in which physical infrastructures often deemed benign can inflict violence on specific regions and social groups. Using a case study of the Takoradi Thermal Power Station in the Western Region of Ghana, the ethnographic research depicts the subtle yet highly deleterious forms of violence that occur within Aboadze, the small-scale fishing community the power station is embedded in, reducing access to vital resources including food, water and land, as well as the various exclusions that impact the livelihoods of a community already suffering from marginalization and poverty.
\end{abstract}

Keywords: Commodity frontiers, infrastructural violence, power station, Sub-Saharan Africa, Ghana

\section{Résumé}

Cette recherche adopte le concept de Jason Moore de la frontière des produits de base, qui dépeint les impacts socio-écologiques de l'expansion capitaliste, pour analyser la propagation de la «fourniture d'énergie indépendante» en Afrique subsaharienne. Cette forme d'approvisionnement énergétique a été sous-théorisée, en particulier ses impacts sur les communautés locales. L'article utilise le concept de «violence infrastructurelle» comme une lentille analytique, pour montrer comment les infrastructures physiques souvent considérées comme bénignes peuvent infliger de la violence à des régions et des groupes sociaux spécifiques. En utilisant une étude de cas de la centrale thermique de Takoradi dans la région occidentale du Ghana, notre recherche ethnographique décrit les formes subtiles de violence qui se produisent à Aboadze, une communauté de pêcheurs à petite échelle. La présence de la centrale électrique à proximité réduit l'accès aux ressources vitales, notamment la nourriture, l'eau et la terre, ainsi que l'imposition de diverses exclusions qui affectent les moyens de subsistance d'une communauté qui souffre déjà de marginalisation et de pauvreté.

Mots-clés: frontières des produits de base, violence infrastructurelle, centrale électrique, Afrique subsaharienne, Ghana

\section{Resumen}

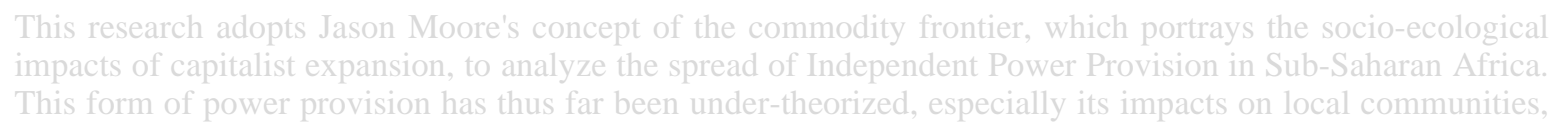

${ }^{1}$ Dr. Callum Nolan, Department of Geography and Environmental Science, University of Reading, UK. Email: c.nolan "at" reading.ac.uk, callum_nolan "at" hotmail.com. Professor Michael Goodman and Dr. Filippo Menga are in the same Department. We would like to thank Simon Batterbury (an alumni of the same Department!) for his support and guidance through the review process and also thank the reviewers who provided helpful comments on earlier drafts of the article. Funding was from the Leverhulme Trust Doctoral Programme in Climate Justice, and the University of Reading. All errors or omissions remain our own. 


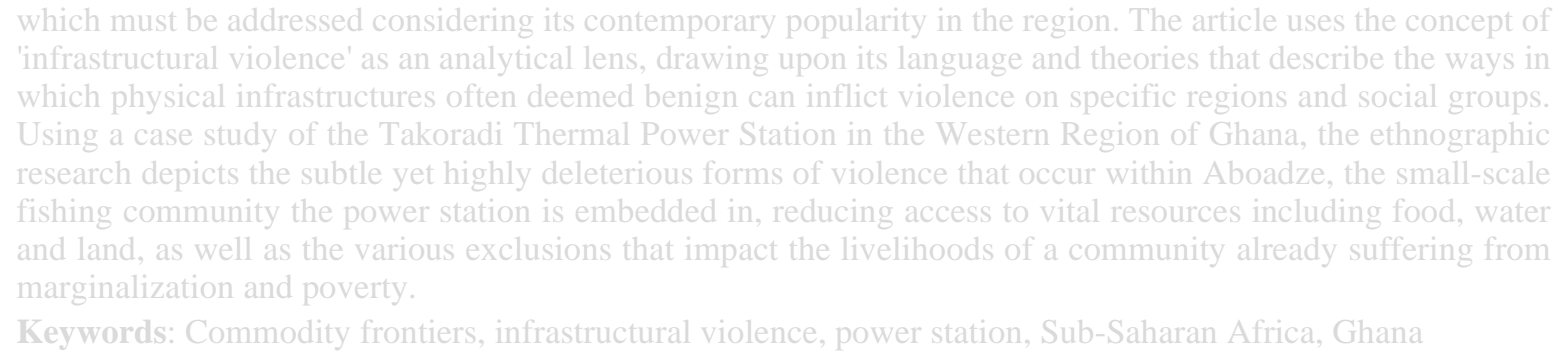

\section{Introduction}

Over the past two decades scholars have increasingly built upon Jason Moore's (2000) concept of the 'commodity frontier' to theorize the expansive nature of capitalism, and the impacts on the yet-to-be commodified spaces that capital seeks out in the hunt for 'cheap' nature - in particular food, raw materials, labor power and energy (Moore 2012). Work to date has found frontier expansion to be a process that challenges existing hegemonies, and that drastically alters patterns of control and access over natural resources, primarily to the detriment of indigenous communities (Dressler and Guieb 2015; Peluso and Lund 2011). Contributions thus far have focused primarily on "surplus land, the conversion of forest for timber, or landscapes being opened for minerals or sown for boom crops" (Fabinyi et al. 2018: 1). This leaves scope to look at the expansion of alternate manifestations of capital, as whilst there are common factors that are observed in frontier expansion (such as power inequalities and changing access to resources), it is also important to note that the process is not entirely homogenous (Agergaard et al. 2009). Variations depend on the type of natural resource and the eventual commodity produced, and the socio-economic environment within which they are situated and circulate (cf. Tsing 2005, 2015).

This article explores the frontier expansion of Independent Power Projects (IPPs) in Sub-Saharan Africa (SSA) and the subsequent infrastructural violence one particular IPP has wrought on a small-scale fishing and farming community in coastal Ghana. IPPs are defined as "power projects that are, in the main, privately developed, constructed, operated and owned; have a significant proportion of private finance; and have longterm power purchase agreements with a utility or another off-taker" (Eberhard et al. 2017: 391). Very little work to date has looked at energy frontiers beyond oil, with some exceptions including Willow and Wylie's (2014) research on fracking, and Woodworth's (2017) work on energy resource frontiers in China. As will be discussed, IPPs have proliferated in the past two decades across Africa, and look to remain a key means through which nations of Sub-Saharan Africa (SSA) will attempt to provide power for a growing population. Understanding these geographical spaces and the impacts of the expansion of IPPs on existing local inhabitants is critical to understanding novel forms of infrastructural violence through the lenses of expanding commodity and capital frontiers and the political ecologies of development. It also sheds light on the injustices of access that these sorts of infrastructure projects visit on marginalized and precarious local communities.

The expansion of capitalism is reliant on the appropriation of natural resources. As Anna Tsing (2005: 50) writes, "natural resources are not God given but must be wrested from previous economies and ecologies in violent extractions." Violence is an unavoidable by-product of this process, however focusing merely on traditional conceptions of violence as an explosive moment involving physical or armed conflict omits its more insidious and latent forms. This article will build upon a long tradition of work by political ecologists who have sought to explore the site-specific causes and manifestations of violence that arise in struggles over access to natural resources (Peluso and Watts 2001; Springer and Le Billon 2016). The specific form of violence we focus on is 'infrastructural violence', where infrastructures that prop up nations, be they roads, power stations or pipelines, are not anywhere near as benign as they are often considered or argued to be by their supporters and funders. An expanding body of literature has shown the various forms of violence, be they direct or temporally dispersed, that are associated with different forms of infrastructural development across a series of empirical settings. The lens of infrastructural violence remains largely unapplied within existing bodies of literature on energy and environmental justice that attempt to look at the inequitable distribution of the externalities of energy systems. 
The research for this article was conducted during eight months of ethnographic fieldwork - from November 2017 to July 2018 - in Aboadze, a fishing community in the Shama district, located in the Western Region of Ghana (Figure 1). This is a traditional small-scale marine fishing (SSMF) community populated largely by canoe fishermen and fish processors and traders, whose livelihoods rely on Ghana's collapsing smallpelagic fishing industry (Environmental Justice Foundation 2019; Figure 2). In addition, Aboadze is home to the Takoradi Thermal Power Station (TTPS), which was first commissioned in 1997 and continues to expand, owned in part by a state-owned private corporation called the Volta Rivers Authority (VRA), with a number of other international agents involved in construction, operation and maintenance. Thus, Aboadze was selected as an appropriate field site as it is both a SSMF community, typical of many in Ghana and Western Africa, and host to an ever-expanding thermal-power enclave. The research methods were primarily ethnographic, mostly taking the form of structured and semi-structured interviews $(n=>100)^{2}$ with community members (60 women and 59 men of various adult ages, the majority of whom derived a livelihood from the fishing industry), local elites and other relevant local and national individuals (such as school teachers, civil servants from relevant government divisions and engineers) and power plant employees (both those working in Aboadze and the national office). Participant observation was conducted in and around the community and the power-plant, including a guided tour of the facilities. Finally, a review of relevant grey literature was conducted. Of particular importance were Environmental Impact Assessments (EIAs) conducted at the various stages of construction and expansion of the power station.

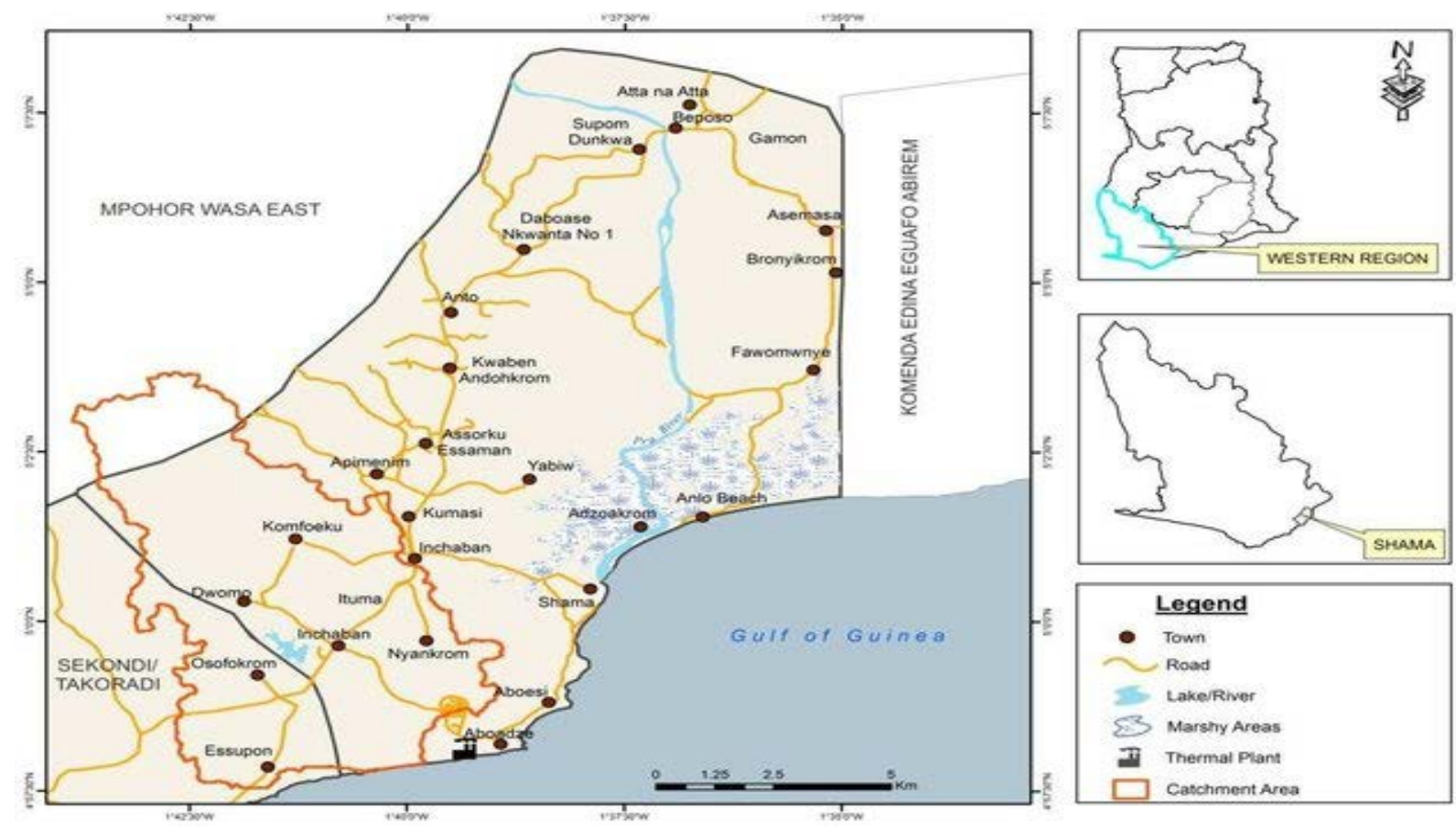

Figure 1: Map of the Shama District. Source: Mireku et al. (2014).

\footnotetext{
${ }^{2}$ Interviews were conducted where possible in English, and otherwise in Fante, the most widely spoken local dialect in Aboadze and then transcribed verbatim alongside an interpreter. Community members were asked general questions about the power station, including their experience of it, their opinions on whether it was good or bad for the community and why, what they expected from the power station and why they felt these expectations should be delivered. Once common themes began to emerge from these and other interviews, more specific follow-up questions were developed and asked. Interviews with members of the VRA covered wide-ranging themes and were conducted both at head office to discuss issues of land acquisition, compensation and CSR and at local levels, to understand the day to day processes and impacts of the plant.
} 
The article continues as follows: Section 2 will explore the development of the concept of violence as used in political ecology, with a focus on the concepts of 'structural' and 'slow' violence. Section 3 introduces the idea of infrastructural violence, which will be used as the key analytical lens for the research. Section 4 reviews existing work that documents the violence associated with energy frontiers. Following this, Section 5 provides the background to the case study, looking at the expansion of IPPs in Sub-Saharan Africa and Ghana, with a more detailed overview of the TTPS. The findings of the empirical work will then be explored and analyzed in Section 6 before Section 7 concludes the article.

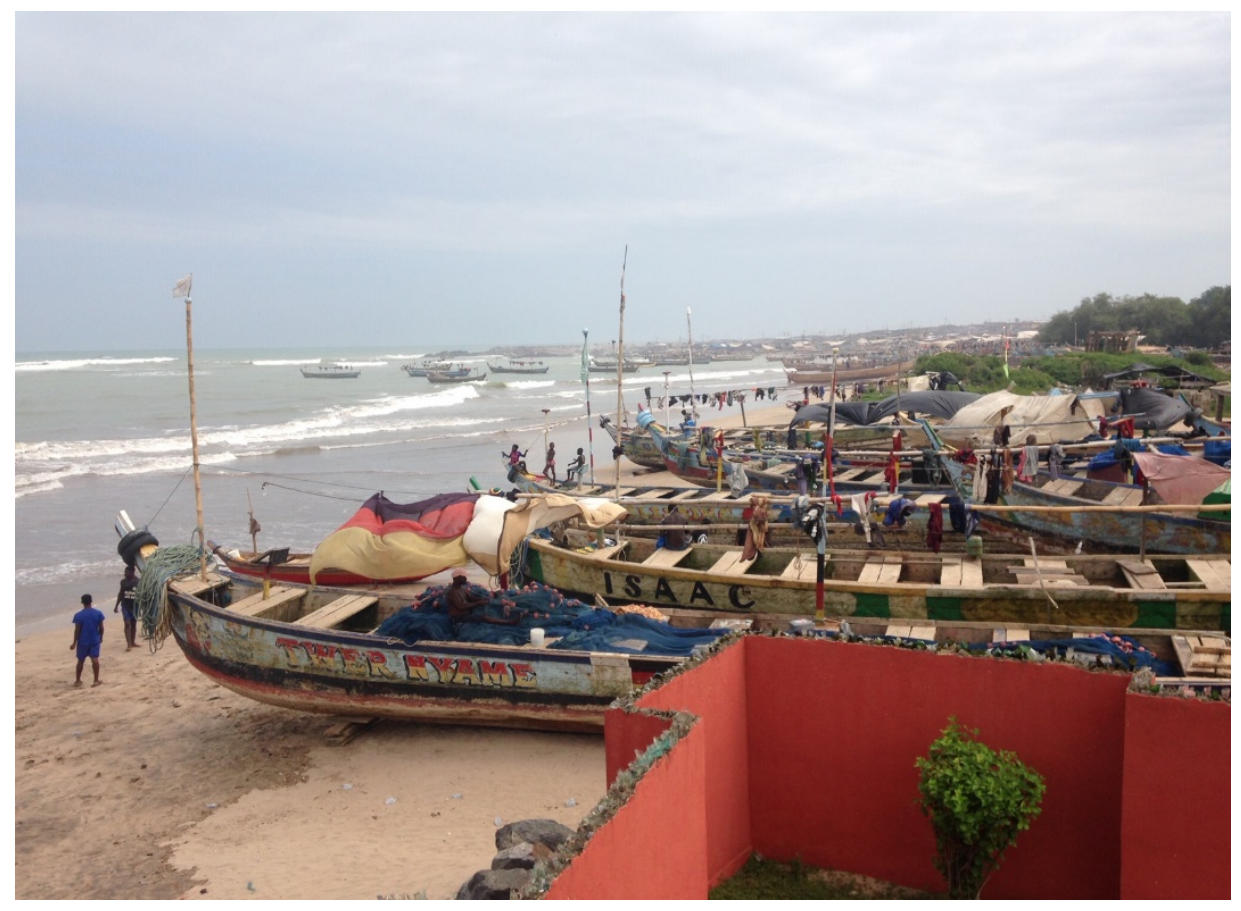

Figure 2: Fishing canoes on the seafront in Aboadze. Source: Author.

\section{The political ecologies of violence}

There are myriad definitions of violence, and conceptually they continue to expand and evolve, applied across a spectrum of fields and institutions (Springer and Le Billon 2016). One widely used definition was coined by the World Health Organization (WHO) at the Global Consultation on Violence and Health. It defines violence as "the intentional use of physical force or power, threatened or actual, against oneself, another person, or against a group or community, that either results in or has a high likelihood of resulting in injury, death, psychological harm, maldevelopment or deprivation." Whilst this is useful in a number of ways, particularly the inclusion of harms beyond merely the physical, it fails to include harms that arise from inaction. This article draws on the following description of violence, taken from the work of Tyner and Rice (2016: 50):

Violence is any action or inaction that affects the material conditions of another, and in so doing, reduces one's potentiality to survive: or to put it another way, violence is any action or inaction that increases vulnerability. Thus, the production of vulnerability constitutes a violent act.

It has been a primary goal of political ecologists to better understand the spatial specificity of violence, and to develop a nuanced understanding of the dialectical relationship between violence and the environment 
(Le Billon and Duffy 2018). Researchers in the field map the constellations of actors attempting to obtain control and access over environmental resources, through the analysis of "the broader logic of protracted violence in which violence that is linked to the environment is embedded" (Bohle and Funfgeld 2007: 669). In their collection Violent Environments, Watts and Peluso (2001) flesh out the political ecologies of violence, foregrounding the importance of local histories and social relations and broader power relations, economic change and material transformations. Political ecologists have sought to dispel Malthusian accounts of environmental conflicts, i.e. too many people and too few resources leading to violent struggles for what is available, instead highlighting both the importance of the specific environment and resources in question, and broader structural imbalances of power, and their implications for control and access over resources. It is this control and access that is central to environmental violence (Watts and Peluso 2001; Allen 2013). The environmental entitlements approach (Leach et al. 1997), which stems from Sen's earlier work on famine (1981), serves as an "ideal starting point" for a political ecology of violence (Bohle and Funfgeld 2007). Entitlements refer to what people can access instead of what they should be able to access. This brings attention to the diverse set of actors who are accessing a given natural resource and the mechanisms and power dynamics that facilitate this. Entitlements and violence are co-constitutive, as divergent entitlements can lead to violence, and can in fact be a form of violence. This has potential to re-shape constellations of entitlements.

There have been several important contributions to our understanding of violence beyond the immediate physical conflicts with which we normally associate it, which is normally represented at a particular temporal and spatial moment. Johan Galtung's (1969) essay 'Violence, peace and peace research' introduced the concept of structural violence, which refers to a violence embedded within a given society that manifests in differentiated power relations, resource distribution and opportunities between social groups stemming largely from political and economic decisions. Central to structural violence is the lack of a clear perpetrator, which differentiates it from classic ideas of violence. Galtung (1969: 171) gives the following example: "when one husband beats his wife there is a clear case of personal violence, but when one million husbands keep one million wives in ignorance there is structural violence." Common manifestations of structural violence are divergent life expectancies, access to healthcare, employment possibilities or education between groups or regions.

Building upon the foundation of structural violence, Rob Nixon (2011) developed the concept of 'slow violence.' Slow violence has bloomed into an increasingly robust concept for understanding forms of violence that occur over a less specified, and often longer temporal scale. As Nixon (2011: 2) describes it, slow violence is "a violence that occurs gradually and out of sight, a violence of delayed destruction that is dispersed across time and space, an attritional violence that is typically not viewed as violence at all." Much of the work in slow violence focuses on environmental issues, with examples given by Nixon including climate change, deforestation, ocean acidification and pesticide poisoning. Slow violence has been used as a tool to look at the impacts of extractive and heavy polluting industries, for example Gamu and Dauvergne's (2018) work on mining activities in Peru, which found slow violence was inflicted through degradation of water and land, and the displacement of communities in the vicinity. These are all symptoms that occur not in a flash of explosive violence (although they may lead to this) but over the months and years to come. The effects of this slow violence are seldom distributed randomly or evenly, with the impacts felt worst amongst those already victim to societal and ecological injustices (Davies 2018), dubbed the "designated expendable" (Nixon 2011: 151). These alternate conceptions of violence, that place the phenomenon on a broader spatial and temporal scale, have paved the way for continued progression in this field. Once such progression is the concept of 'infrastructural violence', detailed below.

\section{Infrastructural violence}

This article explores the impacts of the expanding private power frontier, through the analytical lens of infrastructural violence. This concept has arisen following geographers' attempts to look more critically at built infrastructure - which until recently was often considered benign. The relatively small body of work on infrastructural violence explores the harms done to poor and marginalized groups by the design, location, operation of, and exclusion from, infrastructures (Rodgers and O'Neill 2012). At their most basic, infrastructures 
are "built networks that facilitate the flow of goods, people, or ideas and allow for their exchange over space" (Larkin 2013: 328). For a long time, infrastructure avoided critical inspection by social scientists. Increasingly however, it has been identified as an important avenue for ethnographic study, enabling researchers to theorize "how broad and abstract social orderings such as the state, citizenship, criminality, ethnicity and class play out concretely at the level of everyday practice, revealing how such relationships of power and hierarchy translate into palpable forms of physical and emotional harm" (Rodgers and O'Neill 2012: 402). We now recognize infrastructure as something that mirrors and perpetuates social struggles and imbalances of power (Radonic and Kelly-Richards 2015). As highlighted by Star (1999), infrastructure is fundamentally relational, in so far as it can mean different things to different people. On the one hand, infrastructures are capable of invoking powerful feelings of optimism, development and progression - and as such can enchant and captivate the communities within which they are embedded (Harvey and Knox 2012). On the other, they can be seen as hostile incursions into a territory often being met with varying degrees of resistance by host communities.

But in what ways can infrastructure be violent? Rodgers and O'Neill (2012) articulate differences between active and passive infrastructural violence. Active infrastructural violence is the "conscious development of infrastructure to regulate normative social and territorial relations" (p. 406), characterized by a clear intent for infrastructure to harm, or exclude a particular social group. Although it is unclear from their work, we might also include within this category displacement and changing control over natural resources that can occur from land grabs and processes of enclosure that can often arise from the construction and operation of infrastructure: for example when large areas of land are cleared for the construction of hydraulic dams. Perreault (2018), when describing the infrastructural violence of palm oil plantations, talks of the inevitable large-scale ecological transformations that occur, an example of capitalism's need to acquire natural resources for its reproduction and expansion. Li (2017) also discusses this form of violence, highlighting the 'routinely violent' plantations that monopolize resources and space, suffocating indigenous communities and precluding opportunities for them to maintain and further their livelihoods.

Passive infrastructural violence on the other hand is the unintended social harms that arise "from infrastructure's limitations and omissions rather than its direct consequences" (Rodgers and O'Neill 2012: 407). For example, the violence of excluding certain groups or regions from key utilities, or from the other benefits that many feel infrastructure will afford them. What are the potential consequences of a captivated community who are host to infrastructure, but learn they will be excluded from any of the socio-economic benefits that might be derived from this? Political economy and ecology have long taught us that the economic and ecological benefits and burdens of large projects are often inequitably distributed amongst communities, with money and resources flowing towards those with economic, social and/or political power. Enclosure, be it physical and/or economic, is one means through which existing communities are excluded from deriving benefits from infrastructure.

$\mathrm{Li}$ (2017) talks of infrastructure as enclaved in a "sea of 'normal' towns and villages where other forms of economy thrive", with distinct and often physical demarcation separating the inside from the outside. Those on the inside are often completely isolated from the outside and vice versa, with only limited opportunities for small numbers of the local community to enter, often in the form of low skilled and low paid employment (Perreault 2018). Selective 'entanglement' and 'disentanglement', terms used by Appel (2012) to describe relationships between corporations and states and host communities, produces specific forms of infrastructural violence. In Appel's terms, "where its presence is possible, basic infrastructure's absence is a form of violence" (p. 460). She masterfully demonstrates, through a case study of oil industry enclaves in Equatorial Guinea, how violence is constituted in the juxtaposition of well-maintained housing enclaves, with power and running water, air-conditioning and steady food supplies, against the region outside those walls. Her argument suggests that these oil companies are inherently 'entangled' with local political, social and economic upheaval, yet opt to be 'disentangled' spatially and absolve themselves of any moral and material responsibility outside of their enclaves. Walker and Baxter (2017) suggest that a failure to create opportunities or meet the expectations of host communities will increase the chances of discontent, which can lead to various forms and degrees of resistance. Resistance to the development of infrastructure however, particularly in the early stages, can be quelled by this 'enchantment' - with host communities often mitigating the loss of land against the perceived benefits that might arise or wealth that might be derived from their construction. Resistance becomes more 
likely when it becomes apparent that in most cases, benefits such as free utilities or employment often are only obtained by a select few (Zoomers 2018).

This article seeks to fill theoretical and ethnographic gaps in research to help understand the "tumultuous social and physical transformations resulting from, and produced by, an unfolding frontier of energy production that unsettles social, economic, and ecological landscapes" (Willow and Wylie 2014: 222). Its focus on a fishing community is also important, as power stations are often strategically located in coastal areas so as to enable the extraction of ocean water for cooling their systems and to discard effluents. Sub-Saharan Africa is host to thousands of fishing communities who are reliant on coastal resources in order to maintain their livelihoods. It is such communities, with heavy dependence on natural resources, that find themselves highly vulnerable to energy development given the ecological and economic transformations that can occur (McCauley et al. 2013). These small-scale fishing communities are often politically, geographically and socially marginalized, and are blighted by ecological transformations and declining fish stocks. As discussed elsewhere (Auyero and De Lara 2012), marginalized people do not face infrastructural violence in abstraction from the existing hardships and inequalities that blight their lives. Therefore, by considering the violence of energy infrastructure as inflicted by the TTPS in the context of its specific interactions with the existing issues faced by its host community, we paint a more holistic picture of the violent transformations brought about by this particular form of capitalist expansion.

\section{Violence on the energy frontier}

Research that explores capitalist frontiers has overwhelmingly found them to be violent spaces in which state and corporate actors used a variety of mechanisms to prize natural resources from existing users. As capital floods new frontier regions, many changes occur, not simply in the physical landscape but also in existing power structures, economic opportunities, and demographics. Discourses evolve as new opportunities and hindrances to development become manifest. As far back as the fifteenth century it has been documented how the sugar frontiers ravaged forests in Madeira, so much so that it prompted the extinction of endemic mollusks in the region (Moore 2010). This was of course only made possible by the appropriation of the labor of African slaves, quite possibly the most egregious and prolonged violence against a people ever seen. Tsing (2003) and Hoefle (2006) have more recently reported on the violent frontiers of Indonesia and the Brazilian Amazon respectively, discussing more direct violent conflicts between groups, spurred on by dispossessions and rival claims over land. Importantly, both of these articles embed these instances of violence amongst existing socio-cultural and economic circumstances, such as lingering ethnic tensions which explode back to the surface amidst capitalist rupture.

Energy systems have been heavily associated with violence. Popular media and academic work have linked carbon-based resource extraction with violence in the US invasion of Iraq, and in the Niger Delta with its AK47-wielding insurgents. However, under the broader lens of violence described above, the carbon energy cycle is marred with violence from the initial surveying process to the moment it is expelled from an exhaust and enters the atmosphere. The violence associated with carbon is spatially and temporally unbounded, and is inflicted upon both humans and nature alike. It is a violence that is capable of echoing across generations and regions, and of perpetuating further violence as ecosystems and livelihoods are interrupted, forcing further conflicts over resources. Whilst this violence is almost guaranteed, is it not homogenous, and varies dependent at which stage of the energy cycle it occurs at, and across social, political, cultural and ecological settings. The concepts of the 'energyscape' (Howard et al. 2012) and the 'carbonscape' (Haarstad and Wanvick 2017) help to understand the complex interplay between the supply, demand and production of energy and the landscapes involved. Haarstad and Wanvick describe carbonscapes as "the spaces created by material expressions of carbon-based energy systems and the institutional and cultural practices attached to them. As many theorists have alluded, carbonscapes are shaped at the intersection of infrastructures, technologies, the built environment and various social, cultural and political regimes that govern them" (p. 433).

When considering violent energy frontiers, it is the oil frontiers that have received the most academic attention. The work of Michael Watts $(2007,2012,2018)$ in particular, who has written and researched extensively the complex tapestry of conflict in Nigeria's oil regions, has been invaluable in understanding the 
extent of the violence inflicted by oil upon and between humans and certainly upon surrounding nature. Watts (2012) discusses the rise of the 'Movement for the Emancipation of the Niger Delta' (MEND) in the oil fields of Nigeria, an armed and powerful insurgent group who launched a sustained attack on the oil industry, with five thousand pipeline ruptures in 2007 and 2008, and oil revenues falling by $40 \%$ in this period. Such movements have arisen on account of the toll that oil extraction has taken on its local environments, through oil spills and gas flaring for example. To further fuel this rage, questions of equity, justice and exclusion sit at the forefront of MEND's campaign, as billions of dollars-worth of oil is plundered from their lands, yet abject poverty still characterizes the vast majority of Nigeria's oil communities over half a century after oil was first identified. As Watts himself puts it, "for the vast majority, oil has brought only misery, violence, and a dying ecosystem" (2012: 449). He goes on to describe the ancillary violence that spreads beyond attacks on pipelines and on staff compounds of oil workers, such as inter-community conflicts in which gangs of youth fight in order to access "community development" funds from the oil companies, primarily in return for protection. These patterns of violence can be seen in other empirical settings. A study of the Ecuadorian oil industry discusses the violent territorialization that has arisen concomitantly with the capitalist control of the frontier zones (Gilbert 2018). Whilst violent conflict has been rife, including over 100 deaths over two decades, Gilbert also identifies slower and more subtle forms of violence, including deforestation, despoliation of local ecosystems, alcoholism and prostitution.

Thus far there has been insufficient research into the impacts of infrastructure and the violence it is capable of inflicting when forming part of the carbonscape. The fixed capital of carbon industries in the form of pipes and other infrastructure creates path dependencies, locking communities into decades of living alongside polluting and imposing structures. As Pickren (2019: 48) puts it, these areas around carbon infrastructure are the "sacrifice zones of fossil fuel capitalism", communities deemed expendable in order to facilitate continued capital accumulation. Haarstad and Wanvick (2017) rightly points out that whilst the infrastructure of the carbonscape is capable of creating social and ecologically harmful path-dependencies (power stations are designed to last for decades, locking a nation in to using fossil fuels for this period), it is also characterized by rupture and unpredictability. Power stations, the focus of this article, are a form of infrastructure in so far as they are there to generate and transport energy to households. To the vast majority of populations, they are invisible. In addition, power stations themselves have infrastructure, such as pipes, walls, security gates, storage facilities, accommodation etc. that transform these sacrifice zones, carving through communities and fundamentally changing the landscapes with a host of consequences as this article will show.

\section{Understanding IPPs and new commodity frontiers in Sub-Saharan Africa}

SSA remains considerably behind other regions when it comes to energy access, per capita consumption and generation capacity (Kojima and Trimble 2016). The problem is felt mostly amongst its rural population and urban poor (Mandelli et al. 2016). There are approximately 600 million people in SSA who are thought to lack access to electricity (IEA 2019) primarily excluded as a result of high costs, shortfalls in power generation and insufficient and/or poorly maintained infrastructure (Eberhard and Shkaratan 2012). This is problematic for a number of reasons, particularly due to the poor correlation between better access to electricity and community development through poverty alleviation, reduction of climate vulnerability, improved healthcare and improved literacy (Chirambo 2018; Trotter et al. 2017). This is because rising populations and economic development put more strain on dated power infrastructure, with current trends suggesting that more people will be without access to 'modern energy services' in 2030 than today (Bazilian et al. 2012). It is clear that Africa needs more energy, but cash-strapped governments are often unable or unwilling to provide this unilaterally (Rehman et al. 2012). Because of this, IPPs are frequently heralded as the solution (Gratwick and Eberhard 2011), and now constitute the fastest growing form of power investment in SSA (Eberhard et al. 2017).

The presence of IPPs has marked a neoliberal shift amongst developing nations, seeking private intervention for the advancement of a utility that has traditionally been state-owned. SSA's first IPP was in the Ivory Coast in 1994, and since then they have continued to proliferate, and are present in 20 countries across the continent (Eberhard et al. 2018). Whilst in a number of cases the continued construction and operation of these private power infrastructures has bolstered electric supplies successfully, it is important to recognize that 
the benefits and burdens of energy production are inequitably distributed. This detail has been highlighted in a number of debates, including the emergent work on energy justice (Jenkins et al. 2016), as well as the more established field of environmental justice (Endres 2009; Ottinger 2013). One common pursuit of this work is to look at the impacts of power infrastructure on local communities, with findings that show them to be disproportionately located in poor communities and sites of ecological and social disruption often met with different forms of resistance. Discourses of national progress and utilitarian arguments of the greater good may often overshadow the complex sites where IPPs construct and operate large, unsightly and potentially harmful power generating infrastructure.

Thermal power stations that utilize fossil fuels to generate power are the primary source of independent power generation in SSA (Eberhard et al. 2016). Thermal power generation requires large quantities of water for system cooling and waste disposal, and as such the plants are often located along the coast. SSA coastal communities are considered some of the world's most vulnerable given high rates of poverty, political marginalization and the increasing threat of climate change to their livelihoods, which are often directly dependent on natural resources such as fishing and farming. This article seeks to understand the ways that SSMF communities in SSA are impacted by the expanding frontiers of IPPs.

\section{Power generation in Ghana}

While Ghana boasts one of the highest rates of electrical connectivity for its population within SSA (World Bank 2019), it has nonetheless been blighted, both historically and in modern day by issues around the generation and distribution of power to its people, particularly those in rural areas (Kemausuor et al. 2011). This section will briefly outlay the historical process of electrification in Ghana, providing an overview of existing infrastructure and relevant institutions before highlighting a number of issues that are still faced today. Following this, it will provide more information on the Takoradi Thermal Power Station and the various actors involved in its construction, expansion and operation, which is the focus of this particular case study.

Electricity generation in Ghana has moved incrementally through three key stages, starting with standalone diesel generators usually owned and operated within the mining industry, then the use of hydroelectricity and finally the introduction of thermal power generation. British colonizers first brought electricity to the coastal region of Sekondi in 1914 (which was a hub for the transportation of minerals and timber), followed by the capital Accra in 1922 (Kapika and Eberhard 2013). The decade after independence in 1957 saw important progression, as the VRA was set up in 1961, tasked with the generation and transmission of power. Partly funded by the World Bank and the United States, the Akosombo Dam in the country's Eastern Region created a vast inland lake, and large-scale hydro-electric power generation from 1965 (Kemausuor et al. 2011). Akosombo's generating ability was expanded in 1972, bringing its total hydropower capacity to 912MW, and in 1981 a second hydro-electric plant was opened at Kpong.

The country's reliance on hydropower became problematic however, and beginning in the early 1980s a series of droughts marked the beginning of a tumultuous period of power outages across the country (Kapika and Eberhard 2013). In the face of these recurring blackouts, the VRA and partners recommended the addition of thermal power to the country's power mix to reduce reliance on unreliable rainfall (Kemausuor et al. 2015). The first thermal power station (the Takoradi Thermal Power Station or TTPS) was built in Aboadze in 1997, and over two years additional units were added bringing total capacity to 330MW. The TTPS is under continued expansion to this day. The port city of Tema, east of the capital Accra, now has two thermal power plants opened in the last fifteen years.

Whilst the diversification of electricity generation has undoubtedly gone some way to steadying power supplies in Ghana, the country has faced perennial challenges even after the introduction of thermal power (Brew-Hammond 2010). Ghana has rapidly rising electricity consumption, which is occurring at a rate of around $10 \%$ per annum, driven by development, population growth and urbanization (Atsu et al. 2016). Continued problems arising from lack of fuel supply to the thermal power station, an antiquated distribution network and operational failings at all plants have meant that supply still frequently falls short of demand (Fritsch and Poudineh 2016; Gyamfi et al. 2018). To compound this, Ghana experiences high levels of theft and illegal 
connections, with as much as $30 \%$ of electricity supplied thought to have been lost in this manner (Yakubu et al. 2018).

It is clear that despite its relatively high performance by the standards of SSA - and outside of any largescale movement to turn power generation into a public utility - Ghana needs to increase its power generation capacity and to reduce loss by tackling infrastructural problems. As is typical of neo-liberal reform on the continent, structural change and private investment has been deemed an integral part of improving Ghana's generation capacity (Eberhard et al. 2016). In line with the World Bank's Structural Adjustment Program of 1986, the power sector went through a reformation process in 1994, deregulating the market and unbundling monopolistic power generation and transmission companies to increase competition and private participation (Eshun et al. 2016). The TTPS is very much a hybrid project, with funding, construction and operation divided between private companies, the state and international institutions.

\section{Takoradi Thermal Power Station}

TTPS was the first of Ghana's thermal power stations, commencing operation in 1997 (Figure 3). Despite its name, the power station is in fact located in Aboadze, a small fishing community approximately 15km northeast of Takoradi. As a thermal power station, TTPS operates through the burning of fossil-fuels (natural gas or light crude oil) in order to heat water, creating steam which rotates a turbine, generating electricity. Ghana does not have the capacity to refine oil from its own Jubilee Fields, so is currently entirely dependent on imports (Sakah et al. 2017). Oil is stored on-site in large tanks, fed by tankers that connect to a single-mooring point approximately $4 \mathrm{~km}$ offshore. For some time, the country was similarly reliant on gas imports, powering its station with gas from the West African Gas Pipeline (WAGP), however it has recently been able to obtain gas from its domestic sources.

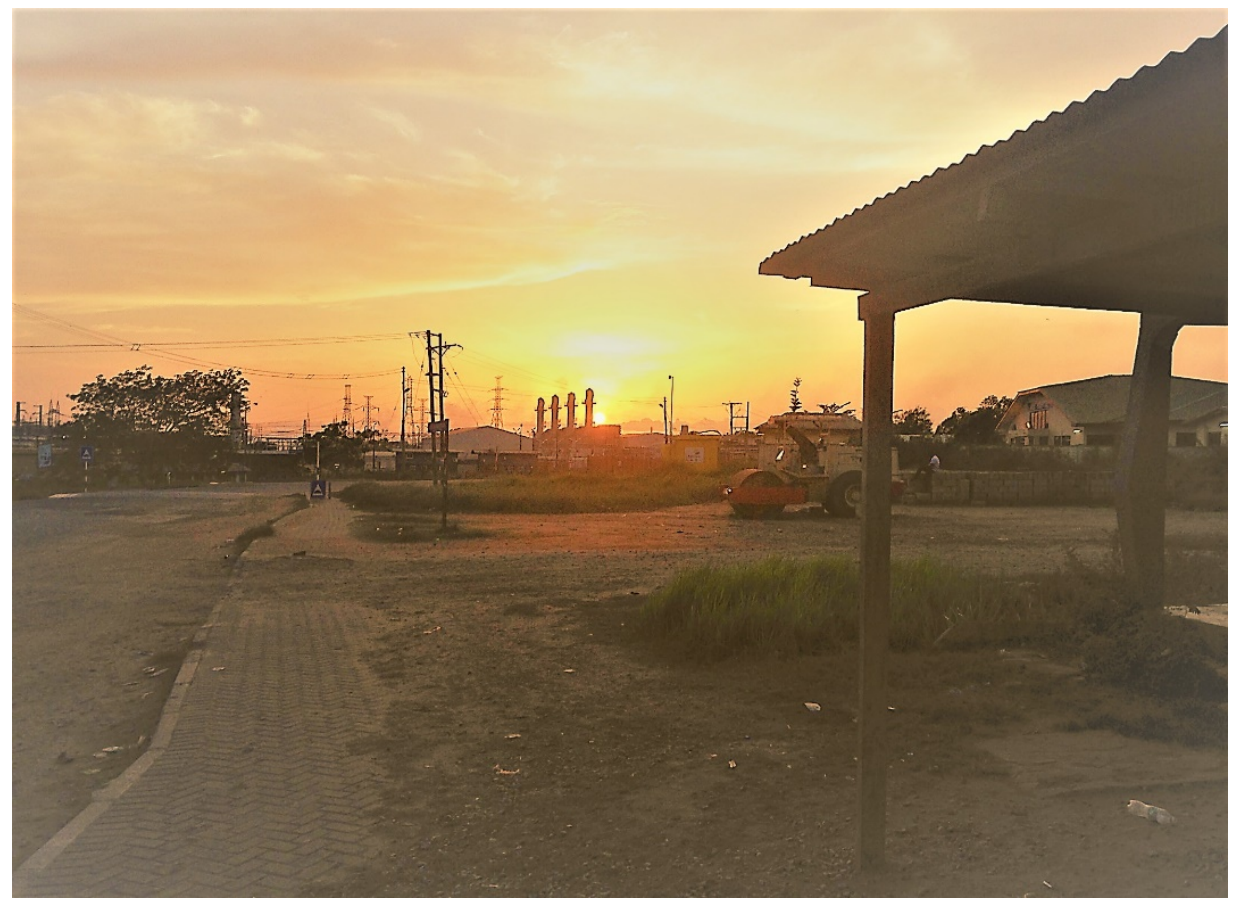

Figure 3: Entry road into Takoradi, with the power station in the background. Source: Author.

TTPS is synonymous with the VRA, who own 'T1' which is the original thermal plant, own 10\% of 'T2' (the remaining percentage is own by TAQA, an international energy corporation listed in Abu Dhabi), and own the currently non-functioning 'T3.' There is also a further power station 'T4' being constructed, and additional 
'simple cycle' capacity added, owned and run by IPPs. Ghana falls considerably short in capital and capabilities when it comes to the construction and design of power stations, creating a complex web of both national and international actors involved in the funding, construction and operation of the generators. Privately owned power stations in Takoradi are contracted under a Build Own Operate and Transfer (BOOT) scheme, in which the companies will eventually transfer ownership and operation to the VRA after a set period of time. Firms such as General Electric, Stone and Webster and AmeriPower from America, METKA of Greece, and Jacobsen of Norway are all invested in the TTPS, and diverse funding comes in from sources such as the World Bank, The Kuwaiti Fund and the European Investment Bank.

The presence of the power station has fundamentally changed the landscape of Aboadze. A road connecting the town to nearby Inchaban (which sits on the main carriageway towards Accra) was built in order to facilitate access for construction. The power station itself continues to expand to the south-west, with construction of the T4 station. The presence of the TTPS has drawn a number of ancillary organizations to the region, including an inlet station of the West African Gas Pipeline and Ghana Gas. There is also a housing enclave with a range of properties, from dormitory accommodation used by lower paid VRA staff to guesthouses, primarily used by those travelling to the TTPS for business. Some of the properties are also used by locals who are not linked to the VRA, including schoolteachers and other professionals. The VRA have also built a hospital, a club house with restaurant and swimming pool and a primary school. Finally, a sea-defense wall has been constructed along the coast nearest the TTPS in order to protect it from rising sea-levels.

\section{Infrastructural violence on a commodity frontier in Ghana}

The processes and impacts of changing access to resources and opportunities that have arisen as a result of the power stations presence in Aboadze, inflict or incite certain forms of violence. Importantly, violence and access to resources have an iterative relationship. Violence "not only perpetuates or reshapes conditions of access and control over resources, but is also transformative of resources and environments" (Le Billon and Duffy 2018: 248). The following sections highlight how the construction and operation of the TTPS has significant implications for access to natural resources, in particular land, food and water, and also exerts infrastructural violence through exclusion of those in its 'sacrifice zone' in and around Aboadze from accessing the socio-economic benefits that it brings (Figure 4).

\section{Reducing access to land and sea resources}

The appropriation of land is common where capitalist accumulation and infrastructural violence occur. Over 180 hectares of coastal lands, with more envisioned, has been taken in order to service the power station and associated infrastructure. Beyond the infrastructure that directly belongs to the power station, ancillary industry is also drawn to the region including facilities developed by WAGP and Ghana Gas. Linked to the industrialization of the area was the arrival of a Chinese tile making company in close proximity to Aboadze. The nature of infrastructure, which is often discursively constructed as existing for the national good, plays a role in the appropriation of the land. Large areas of land in Ghana are either obtained through 'compulsory acquisition' or 'private treaty', the former allowing the state to use its power to seize areas of land for development, and the latter requiring negotiation and a sale agreed by both parties. Given the national importance of the power station, compulsory acquisition was used to obtain this coastal land, which was problematic in a number of ways.

Compulsory acquisition has been commonplace in Ghana since colonial times, and despite the ostensible purpose of furthering the national good, in the Ghanaian context it often results in social inequality, poverty, and tensions between the state and the public (Larbi et al. 2004). One key issue is around the failure of the Ghanaian government to pay compensation to those affected by the loss of land (ibid). Compensation, or lack thereof, was a key complaint that arose from discussions with members of the community. The issue was twofold: firstly, there were claims that the VRA had only compensated for the loss of farms but had not paid for the land purchase, and secondly that compensation money for farms did not reach the intended recipients. Complaints that the VRA did not fully compensate landowners was mentioned in interviews with community leaders, and echoed in local media outlets (GhanaWeb 2015). A number of members of the community stated 
that money to compensate landowners and small-scale farmers was taken by the chief and other elders in the community. Aboadze, like most of Ghana, is controlled by customary land rights, or 'stool' rights, meaning that traditional leaders (in this case the chief) are the owners and custodians of the land. Others have also found that that the roles of chiefs can become problematic, going beyond their roles as guardians. Ahmed et al. (2018: 581) found that chiefs in Ghana "often go beyond their traditional role as custodians of land to behave as land sellers, expropriators, negotiators, receivers of compensation, and conflict arbitrators", and are "major actors in efforts that promote neoliberal agendas in the rural frontiers." A member of VRA staff involved in land purchase and acquisition acknowledged that money being intercepted by chiefs is a potential problem: "In many cases what happens is it [money] goes to the chief's house and then minimal comes out, and here you don't question the chief."

With the construction and consequent growth of the power enclave, the population of the region has by all accounts grown significantly. Whilst the official census shows almost no growth between 2000 and 2010 (from 9,399 to 9,471), it did show that the number of households rose in this period from 840 to 1171. Anecdotally, a number of community members and local elites identified population growth in Aboadze, also reflecting in construction. They put this down to the arrival of the power station, with one senior community member suggested the population might be as much as 20,000 . One local politician echoed this sentiment:

Now we have most of the VRA workers residing in our community and other companies now, most of their workers are residing in our community. In the olden days you can even take a bottle of schnapps to the chief and you would get some lands, or people would say in my house I have nobody to stay with so you can even come and stay as caretaker but now renting is very high, a single room now goes for 50 Ghana [Ghana cedis, about US\$8.50], a single room without basic facilities...

The single rooms described above can be observed in the community; they are rudimentary constructions with no toilet or running water, just single rooms with a bed. A common complaint amongst community members is increasing rent. This is particularly problematic for a community that almost exclusively derives a livelihood from a collapsing fishing industry. Whilst incomes fall to crippling lows due to declining fish stocks, housing prices are driven up by increased demand for land, property and accommodation that accompany the power station, thus creating a difficult and perilous economic context for the livelihoods of many local inhabitants (Figure 4).

Beyond the coastal land, the nearshore of Aboadze has also been impacted by the power station. Extensive pipework exists beneath the shores in the direct vicinity of the power station, primarily serving as a docking point for deliveries of light crude oil when required and as cooling systems to draw and discharge water. In order to protect these, oceans nearby have been privatized, enforced by local navy units. Nearshore areas are particularly important to canoe fishermen in Ghana given that this area is in theory reserved exclusively for them, as it is in the Inshore Exclusion Zone (IEZ) within which industrial trawling is not permitted. In particular, poorer fishermen who use small two or three-person canoes are particularly reliant on these areas, given that their vessels are incapable of enduring longer trips in rougher, deeper seas. These fishermen are already particularly vulnerable, given that they are disproportionate impacted by the decline in fish stocks given their limited mobility at sea.

Aboadze appears to be a clear case of so-called 'ocean grabbing', defined by Bennett et al. (2015: 62) as the

...dispossession or appropriation of use, control or access to ocean space or resources from prior resource users, rights holders or inhabitants. Ocean grabbing occurs through inappropriate governance processes and might employ acts that undermine human security or livelihoods or produce impacts that impair social-ecological well-being. Ocean grabbing can be perpetrated by public institutions or private interests. 


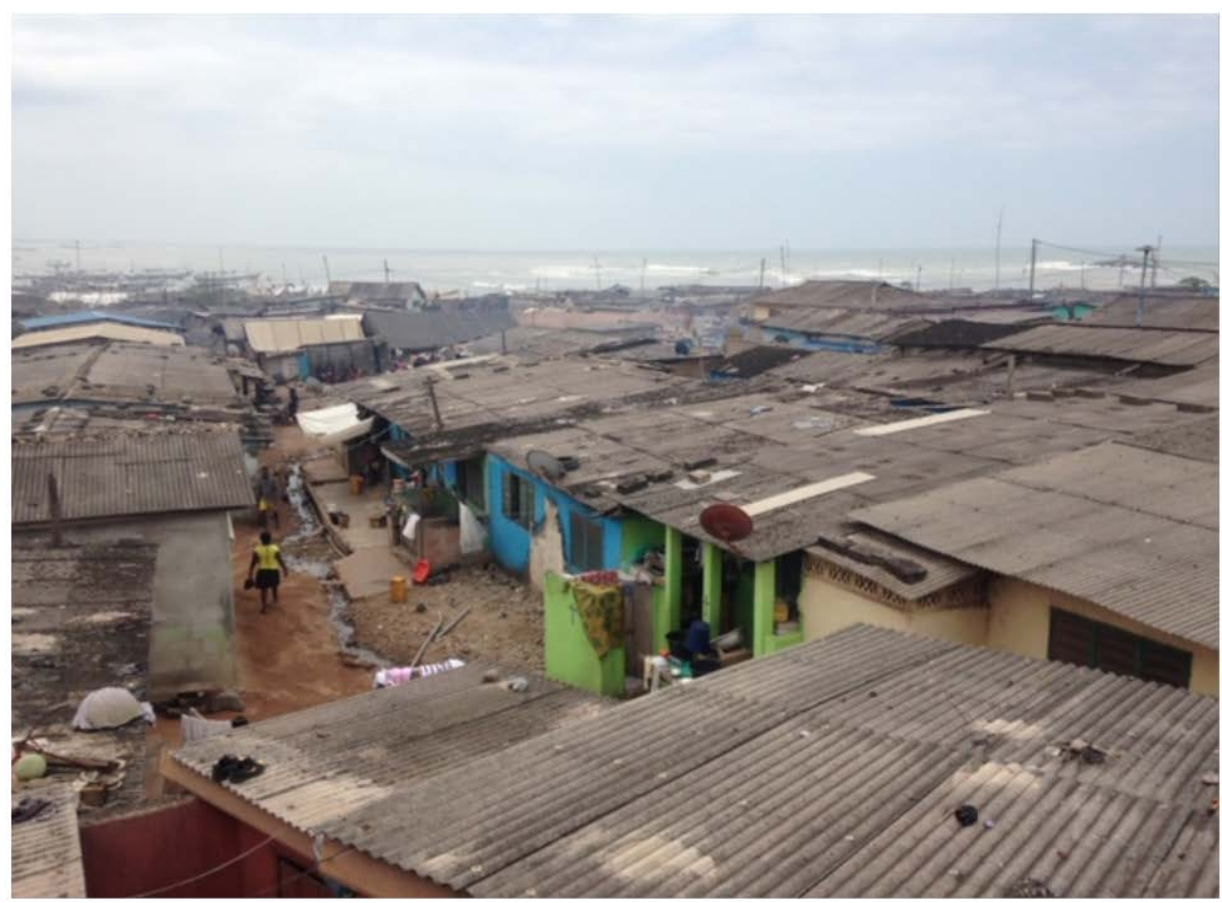

Figure 4: Densely populated housing area near the seafront in Aboadze. Source: Author.

Taking violence as an act that increases vulnerability, we can see that these land and ocean grabs have undeniably inflicted violence upon community members, depriving them of appropriate compensation, taking land and drawing an influx of people that drive up rent prices thereby exacerbating the poverty already harshly experienced by SSMF communities. They also reinforce existing social inequalities, inevitably impacting those who are poorest in the community the hardest. This is exemplified by those who operate small canoes, who are now unable to fish in the local vicinity.

\section{Reducing access to food and increasing food insecurity and debt}

Whilst the increased pressures on land have exacerbated poverty in the community, the loss of crops has also been significant. According to an initial World Bank (1993) assessment, around 40 hectares of small farms existed that grew important staple crops such as cocoyams, cassava, tomatoes and chilies, as well as coconut plantations and a small river where people could catch tilapia and periwinkles. This provided cheap or subsistence food for the local populace, and also employment. Farming is important for coastal communities, because fishing is seasonal. During the 'lean' season fishermen and their families can farm to obtain food and financial security (Geheb and Binns 1997). Due to the development and expansion of the power station, coupled with the lack of availability of new land in the area, small farms are now almost non-existent in Aboadze and most food is brought in from outside, with associated costs.

Again, we see the compounded impacts of two major stressors on the community, at a number of levels. With small pelagic fish stocks critically low, less fish than ever circulate in Aboadze. This has obvious impacts on food security, which will be further exacerbated by the disappearance of farms in the region. Declining fish stocks also mean that available fish, often purchased from cold stores in the area (Nolan 2019), are considerably more expensive. Therefore, the availability of low cost, staple foods either as an alternative or supplement to fish as a protein is vital, and their absence can be catastrophic. Lean seasons in particular become periods of real concern and depravation. Where fisherfolk would once smoke and store fish to sell and consume during 
these periods, or farm in order to bring in income or sustenance, declining fish stocks and lack of farmland have now all but eradicated both of these options, forcing people into poverty, food insecurity and/or debt.

\section{Reducing access to clean water supplies}

The presence of the power station has also changed systems of access to potable water in the region. The power station is fed by the Anankwari River, via the nearby Inchaban headworks water treatment plant. A reservoir on site at the plant is filled, before the water is further distributed as required. The water requirements of the plant are various, including potable water to offices and accommodation, pre-treatment of light crude oil, fire and service water, and water for $\mathrm{NO}_{\mathrm{x}}$ control. An initial Environmental Impact Assessment by the World Bank (1993) suggested the original plant would require $1500 \mathrm{~m}^{3}$ daily, with this amount growing as the plant has continued to expand. The plant has had a dedicated line installed from the Inchaban headworks, which is now the only fresh water supply into Aboadze, from which water is diverted to communal filling stations in the center of town. Water supply into Aboadze is sporadic, with frequent outages creating perilous shortages. The most likely explanation for this is that levels of water at Inchaban are reportedly very low, and water to the plant is prioritized given its national importance, meaning that the VRA can shut off water to Aboadze when required. Employees at the water treatment plant in Inchaban said that the growing industrialization of Aboadze, coupled with insufficient rainfall has put considerable strain onto water supplies, so much so that a pump was installed due to the failure of the treatment center's usual gravity-fed system. Whilst the VRA would once call frequently to shut off supply to their reservoir, this now apparently rarely occurs, implying that demand for water from the plant has risen considerably.

When water is no longer available for the community pipes, community members become reliant on other, generally more expensive sources of water. A number of privately-owned polypropylene tanks exist in the community, which are more costly and unreliable. Alternatively, the community members charter taxis or minibuses to access water in nearby Inchaban, which given the levels of poverty in the region provides a further source of financial strain. A water tap exists outside of the VRA Township and members of the community can come and fill up large water containers here, although when they will be able to do so is seemingly at the behest of management. Groups of children are frequently seen carting water either on a large trailer or in wheelbarrows back to their homes, which has by a number of accounts resulted in road accidents (particularly late at night when they road is dimly lit). Coastal rural communities are particularly vulnerable in one sense to water shortages, due to the fact that coastal ground water often has high levels of salinity making it unpotable (Ferguson and Gleeson 2012). A number of community members also raised concerns about using rainwater, which is again another important source of water for rural communities, through fear of acid rain, although VRA staff members said they do not believe this is an issue in the region.

\section{Complicated access to local employment}

Discussions with older community members in Aboadze suggest that when the power station was first announced as being located in Aboadze, the overwhelming feeling was excitement and optimism around the opportunities it might afford the community. At the forefront of the opportunities people had hoped would be bestowed upon them is employment. In the face of a decimated artisanal marine fishing community, the need for gainful employment has grown increasingly critical in the area, with the majority of participants angry at the power station for not employing residents. A clear sense of injustice emanated from a number of respondents, often arising from the fact that their lands have been taken, but they have received nothing in return. One member of the community noted: "They have destroyed all the lands. Our grandparents' farms, that we can go to if we don't have any work and need something from it to eat, but they have destroyed it and their grandchildren that are in the house they must employ them, but they do not." This sentiment was echoed elsewhere: "Before there used to be farming but now the plant has come, they have taken all the lands. When you go to them for employment, they don't pick us, when they go to the plant, they are told they are fishermen and won't get employment as they do not train people there, they want ready people." Ultimately this is a case of what Tania Li (2017) terms 'surplus populations': communities who are surplus to the needs of capital. The IPP frontier needed the land of the community, but not the workforce. This differs from some iterations of 
'accumulation by dispossession' common in West Africa, where land is taken from peasants, and they are then required to work it afterwards as employees of agribusiness companies on disadvantageous terms (cf. Luxemburg 2003 [1913]; Cowan and Shenton 1996). ${ }^{3}$

Many of the staff who work at the power station are European and Asian, brought in and out by bus from international hotels in nearby Takoradi. Members of the Aboadze community are normally only employed in low paid and precarious roles, such as security guards, cleaners and kitchen staff. The increasing precarity that characterizes the livelihoods of the fishing-dependent community seems to make the sense of injustice all the more acute. When people bemoan the lack of jobs made available it is often placed against the backdrop of community youths sitting idle: "We are begging that the VRA should every month give them (the elderly) some small money. For instance, I have a child and am advanced in age and my child is also not working, how is he going to look after me if he is also not working?" A thriving fishing industry would likely go some way to alleviate this sense of injustice, as it would be far more profitable than the non-technical jobs that are on offer at the plant. Beyond this, it seems that fishermen are stigmatized at a national level, with regards to their mind set, motivation and education levels. Throughout the course of this research, mention was made to the selfishness of fishermen, the fact that they would all leave construction sites when the bumper fishing season started, that they are responsible for their own inability to capture fish and do not work hard enough. One VRA member of staff said "When they say there is a declining fish stock I disagree completely, I think they are not working hard enough [. . . I I think these guys should up their game, try to you know learn new methods and if possible do land fishing, fish rearing or something instead of sitting there complaining." Attitudes such as this align with studies that find SSMF communities to be socially and politically isolated (Bene et al. 2010), and reflect opinions that political ecologists have perpetually tried to disprove around rural resource users.

\section{Problematic access to local infrastructure}

Aboadze is devoid of much of what would be considered basic infrastructure, including access to toilets, steady access to clean water, access to sewage infrastructure and access to reliable electricity. During our fieldwork, concerns over the problematic access to two forms of infrastructure were starkly revealed: first access to clean and constant supplies of water which has been covered above, and second, reliable electricity. As one community member put it to me: "We are really suffering in this community [...] we are pleading that what we need is water and light and for our children that have been to school should be given jobs so they can care for us. The community, we are suffering hardships." Questions of justice and responsibility are raised by this lack of infrastructure. Electricity is expensive and unreliable, with blackouts causing people to overheat when fans are not working, and causing fridges to turn off spoiling food, and leaving houses in the dark. Meanwhile the VRA compound is constantly supplied with potable water and with electricity, juxtaposing starkly with the town within which it is embedded. When asked what they expected from the VRA, the vast majority of participants listed light as a main priority, justified through a quid pro quo logic: 'they have our land, so should provide us with light.'

At a larger scale, many people in the community believe the VRA is duty bound to assist in the development of the community, particularly given that they bear the costs of VRA's externalities and local impacts. The VRA, and various IPPs that constitute the power station are undeniably entangled in the political, social and ecological makeup of Aboadze. The nature of the VRA however, as a state-owned, but private corporation enables its selective disentanglements. Whilst their links to governments must inevitably facilitate processes such as land acquisition, their status as a private company also allows them to alleviate their responsibilities to the local community. Community level engagement and CSR efforts appear shallow and fail to actively recognize or meet the needs of local people. For example, the VRA school within the compound, whilst open to the public, is completely unaffordable to the vast majority of the community, particularly those who derive a living from fishing. Many members of the community complained that they were treated as second class citizens in the VRA hospital, and that staff members would always be prioritized over them. These shallow engagements are likely a reflection of CSR policy, which very much ties in with corporate ethos as opposed to

\footnotetext{
${ }^{3}$ Many thanks to one of the reviewers for suggesting these references.
} 
that of a government. A member of VRA head office discussed the 'triple bottom line' approach of their CSR policies, essentially highlighting the need for the corporation, the environment and the community to benefit: "So unlike before when the VRA did a lot more of these things on a charity basis, we are doing things strategically now and it kind of does not sit well with the community."

\section{Conclusions}

The expansion of capitalism is an inevitably violent process, challenging and changing existing systems of control and access over resources, reinforcing existing social injustices and harming, if not decimating, local ecologies. This article has sought, through the analytical lens of infrastructural violence, to show the specific forms of violence that accompany the commodity and capital frontiers of independent power generation. This was done by specifically looking at the impacts of the TTPS on the community of Aboadze in its occluded access to land and sea, the increase in food insecurity and problematic access to clean and consistent water supplies, the concerns over local employment and lack of electricity infrastructure. Understanding violence in its broader sense as an increase in the vulnerability of a person or group, or to reduce their ability to survive, can elucidate the violence associated with seemingly benign or 'helpful' projects and actions. With theoretical inspiration from political ecology, the violence caused by the TTPS is detailed by mapping the ways in which access to natural resources and socio-economic benefits has changed within the community impacted by it. The reduction of, and exclusion from, access to these everyday resources, environment and infrastructures increases vulnerability and, in this case, furthers the precarity that already characterizes the life of small-scale fishing communities in West Africa.

Work on commodity frontiers has primarily focused on boom crops. This article has contributed to the field by exploring alternate, but equally damaging, manifestations of capital expansion in the form of independent power generation, unpacking the various ways in which it harms existing community members. It is important to understand the subtler forms of violence that are associated with this model of energy production, particularly in regions such as SSA where environmental injustices are often more commonplace due to deficiencies in governance and tenure systems, and existing levels of poverty and social injustice are high. SSA is an ideal empirical setting for such work, as IPPs are the region's fasting growing form of power investment (Eberhard et al. 2017), making up 25\% of the current power supply (excluding South Africa) and they are widely touted as a means of addressing an exponentially increasing demand for power on the continent (Eberhard 2016; General Electric 2018; IEA et al. 2019).

The article has found that the presence of the TTPS has constrained access to a series of vital natural resources for many of the residents of Aboadze, including land, sea, food and water. Facilitated by huge amounts of international capital and legal processes that allow for the compulsory acquisition of traditional land, a key part of Ghana's power infrastructure has been developed and continues to grow in a small fishing community. The metabolism of power infrastructure demands huge amounts of water, power and land, and creates harmful effluent that spews out into the atmosphere and the sea. All of these have had a deleterious impact on those living within the 'sacrifice zone', as prices of land, food and water all rise, adding to the poverty being faced by small-scale fishing communities and creating even more urgent food insecurity at a time when small-pelagic fish stocks in the region are near collapse. Beyond these very clear and tangible harms that have been caused by this power infrastructure, and the infrastructure (such as pipes, walls, and waste disposal facilities) that constitutes it, this study has also shown how passive infrastructural violence occurs through its omissions and limitations. Local members of the community have found themselves excluded almost entirely from any of the socio-economic benefits of the power station, including jobs and access to infrastructure and these exclusions are felt all the more starkly due to the presence of functioning infrastructure behind the walls of the power station and its housing enclaves, and the corresponding lack of basic infrastructure in the community.

\section{References}

Auyero, J and A. de Lara. 2012. In harm's way at the margins. Ethnography 13(4): 531-557.

Agergaard, J., N. Fold and K. Gough. 2009. Global-local interactions: socioeconomic and spatial dynamics in Vietnam's coffee frontier. Geographical Journal 175(2): 133-145. 
Ahmed, A., E. Kuusaana and A. Gasparatos. 2018. The role of chiefs in large-scale land acquisitions for jatropha production in Ghana: insights from agrarian political economy. Land Use Policy 75(1): 570582.

Allen, M. 2013. Melanesia's violent environments: towards a political ecology of conflict in the western Pacific. Geoforum 44: 152-161.

Appel, H.C. 2012. Walls and white elephants: oil extraction, responsibility, and infrastructural violence in Equatorial Guinea. Ethnography 13(4): 439-465.

Atsu, D., E.O. Agyemang and S.A.K Tsike. 2016. Solar electricity development and policy support in Ghana. Renewable and Sustainable Energy Reviews 53: 792-800.

Bavinck M., F. Berkes, A. Charles, A. Dias, N. Doubleday, P. Nayak and M. Sowman 2017. The impact of coastal grabbing on community conservation-a global reconnaissance. Maritime Studies 16(8): 1-17.

Bazilian, M., P. Nussbaumer, H-H. Rogner, A. Brew-Hammond, V. Foster, S. Pachauri, E. Williams, M. Howells, P. Niyongabo, L. Musaba, B. O Gallachoir, M. Radka and D. Kammen. 2012. Energy access scenarios to 2030 for the power sector in sub-Saharan Africa. Utilities Policy 20(1): 1-16.

Bene, C., B. Hersoug and E.H. Allison. 2010. Not by rent alone: analysing the pro-poor functions of small-scale fisheries in developing countries. Development Policy Review 28: 325-358.

Bennett, N., H. Govan and T. Satterfield. 2015. Ocean grabbing. Marine Policy 57(1): 61-68.

Bohle, H. and H. Funfgeld. 2007. The political ecology of violence in Eastern Sri Lanka. Development and Change 38(4): 665-687.

Brew-Hammond, A. 2010. Energy access in Africa: challenges ahead. Energy Policy 38(5): 2291-2301.

Chirambo, D. 2018. Towards the achievement of SDG 7 in sub-Saharan Africa: creating synergies between Power Africa, Sustainable Energy for All and climate finance in-order to achieve universal energy access before 2030. Renewable and Sustainable Energy Reviews 94: 600-608.

Cowen, M.P and W.R. Shenton. 1996. Doctrines of development. London: Routledge.

Davies T. 2018. Toxic space and time: slow violence, necropolitics, and petrochemical pollution. Annals of the American Association of Geographers 108(6): 1537-1553.

Dressler, W.H. and E.R Guieb. 2015. Violent enclosures, violated livelihoods: environmental and military territoriality in a Philippine frontier. Journal of Peasant Studies 42(2): 323-345.

Eberhard, A., K. Gratwick, E. Morella and P. Antmann. 2016. Independent Power Projects in Sub-Saharan Africa: lessons from five key countries. Washington DC: World Bank.

Eberhard, A., H. Gratwick, E. Morella and P. Antmann. 2017. Independent Power Projects in Sub-Saharan Africa: investment trends and policy lessons. Energy Policy 108(1): 390-424.

Eberhard, A. and M. Shkaratan. 2012. Powering Africa: meeting the financing and reform challenges. Energy Policy 42: 9-18.

Endres, D. 2009. From wasteland to waste site: the role of discourse in nuclear power's environmental injustices. Local Environment 14(10): 917-937.

Environmental Justice Foundation. 2019. Stolen at sea. How illegal 'saiko' fishing is fuelling the collapse of Ghana's fisheries. London: EJF.

Eshun, M.E. and J. Amoako-Tuffour. 2016. A review of the trends in Ghana's power sector. Energy, Sustainability and Society 6(1): 1-10.

Fabinyi, M., W.H. Dressler and M. Pido. 2018. Access to fisheries in the maritime frontier of Palawan Province, Philippines. Singapore Journal of Tropical Geography 40(1): 1-19.

Ferguson, G. and T. Gleeson. 2012. Vulnerability of coastal aquifers to groundwater use and climate change. Nature Climate Change 2: 342-345.

Fritsch, J. and R. Poudineh. 2016. Gas-to-power market and investment incentive for enhancing generation capacity: an analysis of Ghana's electricity sector. Energy Policy 92: 92-101.

Galtung, J. 1969. Violence, peace and peace research. Journal of Peace Research 6(3): 167-191. 
Gamu, J. and P. Dauvergne. 2018. The slow violence of corporate social responsibility: the case of mining in Peru. Third World Quarterly 39(5): 1-17.

Geheb, K. and J.A. Binns. 1997. 'Fishing Farmers' or 'Farming Fishermen'? The quest for household income and nutritional security on the Kenyan shores of Lake Victoria. African Affairs 96 (1): 73-93.

General Electric. 2019. Re-imagining the future of power in Sub-Saharan Africa. General Electric Company. Available: https://www.ge.com/content/dam/gepowerpw/global/en_US/documents/regions/africa/Reimagining\%20the\%20future\%20of\%20power\%20in\%20Sub-Saharan\%20Africa_Digital.pdf～Last accessed 03/05/20.

Ghana Web. 2015. Three Shama royal families demand money from VRA. Available: https://www.ghanaweb.com/GhanaHomePage/NewsArchive/3-Shama-royal-families-demand-moneyfrom-VRA-364703. Last accessed 15/09/2019.

Gilbert, D. 2018. Territorialization in a closing commodity frontier: the Yasuní rainforests of West Amazonia. Journal of Agrarian Change 18(2): 229-248.

Gratwick, K and A. Eberhard. 2011. IPPs in Sub-Saharan Africa: determinants of success. Energy Policy 39 (1): 5541-5549.

Gyamfi, S., F. Amankwah Diawuo, E. Nyarko Kumi, F. Sika and M. Modjinou. 2018. The energy efficiency situation in Ghana. Renewable and Sustainable Energy Reviews 82: 1415-1423.

Haarstad, H. and T. L. Wanvik. 2017. Carbonscapes and beyond. Progress in Human Geography 41(4): 432450.

Harvey, P. and H. Knox. 2012. The enchantments of infrastructure. Mobilities 7(4): 521-536.

Hoefle, S. 2006. Twisting the knife: frontier violence in the Central Amazon of Brazil. Journal of Peasant Studies 33(3): 445-478.

Howard, D.C., P.J. Burgess, S.J. Butler, S.J. Carver, T. Cockerill, A.M. Coleby, G. Gan, C.J. Goodier, D. Van Der Horst, K. Hubacek, R. Lord, A. Mead, M. Rivas-Casado, R.A. Wadsworth and P. Schofield. 2012. Energyscapes: linking the energy system and ecosystem services in real landscapes. Biomass and Bioenergy 55: 17-26.

International Energy Agency, International Renewable Energy Agency, United Nations Statistics Division, World Bank and World Health Organization. 2019. Tracking SDG 7: The energy progress report 2019. Washington DC: IEA.

Jenkins, K., D. McCauley, R. Heffron, H. Stephan and R. Rehner. 2016. Energy justice: a conceptual review. Energy Research and Social Science 11: 174-182.

Kapika, J. and A. Eberhard. 2013. Power-sector reform and regulation in Africa: lessons from Kenya, Tanzania, Uganda, Zambia, Namibia and Ghana. Cape Town: HSRC Press.

Kemausuor, F., G.Y. Obeng, A. Brew-Hammond and A. Duker. 2011. A review of trends, policies and plans for increasing energy access in Ghana. Renewable and Sustainable Energy Reviews 15(9): 5143-5154.

Kemausuor, F., I. Nygaard and G. Mackenzie. 2015. Prospects for bioenergy use in Ghana using Long-range Energy Alternatives Planning model. Energy 93: 672-682.

Kojima, M. and C. Trimble. 2016. Making power affordable for Africa and viable for its utilities. Washington DC: World Bank.

Larbi, W.O., A. Antwi and P. Olomolaiye. 2004. Compulsory land acquisition in Ghana: policy and praxis. Land Use Policy 21(2): 115-127.

Larkin, B. 2013. The politics and poetics of infrastructure. Annual Review of Anthropology 42(1): 327-343.

Leach, M., R. Mearns and I. Scoones. 1997. Environmental entitlements: dynamics and institutions in Community-Based Natural Resource Management. World Development 27(2): 225-247.

Le Billon, P. and R. Duffy. 2018. Conflict ecologies: connecting political ecology and peace and conflict studies. Journal of Political Ecology 25: 239-260.

Li, T.M. 2017. After the land grab: infrastructural violence and the "Mafia System" in Indonesia's oil palm plantation zones. Geoforum 96: 328-337. 
Li, T.M. 2017. After development: surplus population and the politics of entitlement. Development and Change 48(6): 1247-1261.

Luxemburg, R. 2003(1913). The accumulation of capital. London: Routledge.

Mandelli, S., J. Barbieri, R. Mereu and E. Colombo. 2016. Off-grid systems for rural electrification in developing countries: definitions, classification and a comprehensive literature review. Renewable and Sustainable Energy Reviews 58: 1621-1646.

Mireku, O.D., P.K Acheampong, S. Mariwah, S. Daudu and G. Atampugre. 2014. Institutional arrangements for managing watersheds in Ghana: a study of the Inchaban watershed. International Research Journal of Natural and Applied Science 1(3): 38-60.

Morrissey, J. 2017. The energy challenge in sub-Saharan Africa: a guide for advocates and policy makers: Part 2: Addressing energy poverty. Oxfam Research Backgrounder series. Oxford: Oxfam.

Moore, J.W. 2000. Sugar and the expansion of the early modern world-economy: commodity frontiers, ecological transformation, and industrialization. Review 23(3): 409-433.

Moore, J.W. 2010. Madeira, sugar, and the conquest of nature in the "first" Sixteenth Century, Part II: from regional crisis to commodity frontier, 1506-1530. Review 33(1): 1-24.

Moore, J.W. 2012(2010). Cheap food and bad money: Food, frontiers, and financialization in the rise and demise of neoliberalism. Review 33(2-3): 125-161

Nixon, R. 2011. Slow violence and the environmentalism of the poor. Cambridge: Harvard University Press.

Nolan, C. 2019. Power and access issues in Ghana's coastal fisheries: a political ecology of a closing commodity frontier. Marine Policy 108.

Ottinger, G. 2013. The winds of change: environmental justice in energy transitions. Science as Culture 22(2): 222-229.

Peluso, N.L. and C. Lund. 2011. New frontiers of land control: introduction. Journal of Peasant Studies 38(4): 667-681.

Peluso, N. and M.J. Watts (eds.). 2001. Violent environments. Ithaca, NY: Cornell University Press.

Perreault, T. 2018. The plantation and the mine: comment on "After the land grab: infrastructural violence and the 'mafia system' in Indonesia's oil palm plantation zone" by Tania Li. Geoforum 96: 345-347.

Pickren, G. 2019. The frontiers of North America's fossil fuel boom: BP, Tar Sands, and the re-industrialization of the Calumet Region. Journal of Political Ecology 26: 38-56.

Radonic, L. and S. Kelly-Richards. 2015. Pipes and praxis: a methodological contribution to the urban political ecology of water. Journal of Political Ecology 22: 389-409.

Rehman, I., A.Kar, M. Banerjee, P. Kumar, M. Shardul, J. Mohanty and I. Hossain. 2012. Understanding the political economy and key drivers of energy access in addressing national energy access priorities and policies: African perspective. Energy Policy 47(1): 27-37.

Ribot, J. and N.L. Peluso. 2009. A theory of access. Rural Sociology 68(2): 153-181.

Rodgers, D. and B. O'Neill. 2012. Infrastructural violence: introduction to the special issue. Ethnography 13(4): 401-412.

Sakah, M., F.A. Diawuo, R. Katzenbach and S. Gyamfi. 2017. Towards a sustainable electrification in Ghana: a review of renewable energy deployment policies. Renewable and Sustainable Energy Reviews 79: 544557.

Sen, A. 1981. Poverty and famines: an essay on entitlement and deprivation. Oxford: Clarendon.

Springer, S. and P. Le Billon. 2016. Violence and space: an introduction to the geographies of violence. Political Geography 52: 1-3.

Star, S. 1999. The ethnography of infrastructure. American Behavioural Scientist 43(3): 377-391.

Tsing, A.L. 2003. Natural resources and capitalist frontiers. Economic and Political Weekly 38(48): 5100-5106.

Tsing, A.L. 2005. Friction: an ethnography of global connection. Princeton, NJ: Princeton University Press. 
Tsing, A.L. 2015. The mushroom at the end of the world: on the possibility of life in capitalist ruins. Princeton, NJ: Princeton University Press.

Trotter, P.A., M.C. McManus and R. Maconachie. 2017. Electricity planning and implementation in subSaharan Africa: a systematic review. Renewable and Sustainable Energy Reviews 74: 1189-1209.

Tyner, J and S. Rice. 2016. To live and let die: food, famine, and administrative violence in Democratic Kampuchea, 1975-1979. Political Geography 52: 47-56.

Walker, C. and J. Baxter. 2017. " It's easy to throw rocks at a corporation": wind energy development and distributive justice in Canada. Journal of Environmental Policy and Planning 19(6): 1-15.

Watts, M.J. 2007. Petro-Insurgency or criminal syndicate? Conflict and violence in the Niger Delta. Review of African Political Economy 34(114): 637-660.

Watts, M.J. 2012. A tale of two gulfs: life, death, and dispossession along two oil frontiers. American Quarterly 64(3): 437-468.

Watts, M.J. 2018. Frontiers: authority, precarity, and insurgency at the edge of the state. World Development 101: 477-488.

Willow, A.J. and S. Wylie. 2014. Politics, ecology, and the new anthropology of energy: exploring the emerging frontiers of hydraulic fracking. Journal of Political Ecology 21: 222-236.

Woodworth, M.D. 2017. Disposable Ordos: the making of an energy resource frontier in western China. Geoforum 78: 133-140.

World Bank. 1993. Takoradi Thermal Plant - Environment Impact Assessment. Washington DC: World Bank. summary

World Bank. 2019. Access to Electricity (\% of population). Available: https://data.worldbank.org/indicator/eg.elc.accs.zs Last accessed 15/09/2019.

Yakubu, O., C.N. Babu and O. Adjei. 2018. Electricity theft: analysis of the underlying contributory factors in Ghana. Energy Policy 123: 611-618.

Zoomers, A. 2018. Plantations are everywhere! Between infrastructural violence and inclusive development. Geoforum 96: 341-344. 